\title{
Fine-scale sampling reveals distinct isolation by distance patterns in chum salmon (Oncorhynchus keta) populations occupying a glacially dynamic environment
}

\author{
E. L. Petrou • J. E. Seeb $\cdot$ L. Hauser $\cdot$ \\ M. J. Witteveen · W. D. Templin · L. W. Seeb
}

Received: 11 February 2013/ Accepted: 16 September 2013/Published online: 19 October 2013

(C) The Author(s) 2013. This article is published with open access at Springerlink.com

\begin{abstract}
Populations with spatially restricted gene flow are characterized by genetic differentiation that may be positively correlated with the geographic distance separating populations, a pattern known as isolation by distance (IBD). Here we examined the fine-scale genetic structure of 66 chum salmon (Oncorhynchus keta) populations spawning in Alaska waterways and explored patterns of IBD using 90 nuclear and 3 mitochondrial single nucleotide polymorphisms. Estimating population structure of chum salmon in Alaska is of increasing concern because of fluctuating census sizes and the uncertain effects of harvest on specific populations. We hypothesized that IBD would be present because chum salmon spawn in coastal rivers that are distributed along a linear array and gene flow is spatially restricted due to homing. Evidence of very weak IBD was found throughout the region $\left(\mathrm{R}^{2}=0.06, p<0.0001\right)$ but the strength of the IBD relationship varied greatly over
\end{abstract}

Electronic supplementary material The online version of this article (doi:10.1007/s10592-013-0534-3) contains supplementary material, which is available to authorized users.

Genotype data are available under DRYAD entry. doi:10.5061/dryad. ds304.

E. L. Petrou · J. E. Seeb · L. Hauser · L. W. Seeb ( $₫)$ School of Aquatic and Fishery Sciences, University of Washington, 1122 NE Boat Street, Box 355020, Seattle, WA 98195-5020, USA

e-mail: 1seeb@uw.edu

\section{J. Witteveen}

Division of Commercial Fisheries, Alaska Department of Fish and Game, 351 Research Court, Kodiak, AK 99615-6327, USA

W. D. Templin

Division of Commercial Fisheries, Alaska Department of Fish and Game, 333 Raspberry Road, Anchorage, AK 99518, USA different spatial scales and geographic regions. Decomposed pairwise regression analyses identified nine outlier populations to regional IBD patterns, suggesting that geographic distance is not the only factor influencing genetic differentiation in the region. Instead, population structure appears to be heavily influenced by glacial history of the region and the presence of a glacial refugium on Kodiak Island.

Keywords Isolation by distance $\cdot$ Population genetics · Chum salmon · Oncorhynchus keta . Single nucleotide polymorphisms

\section{Introduction}

Information on genetic population structure may strengthen conservation plans because it can help describe the appropriate spatial scale for management units (Palsbøll et al. 2007) and identify populations that are small, isolated, and need protection from overharvest (Allendorf et al. 2008). However, recent studies have shown that sampling design can confound interpretations of population structure (Schwartz and McKelvey 2009; Oyler-McCance et al. 2012); for example, coarse-scale or irregular sampling may lead to spurious results of genetic differentiation and restricted gene flow (Schwartz and McKelvey 2009). These findings highlight the importance of sampling at ecologically appropriate spatial and temporal scales to correctly infer the evolutionary and demographic history of wild populations.

Mutation, migration, genetic drift, and natural selection shape the genetic structure of natural populations. The gene pools of spatially segregated populations are connected through dispersal and reproduction (hereafter referred to as migration) events. Populations of some species occupy an 
approximately linear habitat, such as a river or coastline; in this case, populations can be modeled by a one-dimensional stepping stone model (Kimura and Weiss 1964) where migration occurs more frequently between adjacent populations. When migration is spatially limited in this way, genetic differentiation is positively correlated with the geographic distance separating populations, a pattern known as isolation by distance (IBD) (Wright 1943). IBD is a commonly tested hypothesis in population genetics, and this pattern has been observed in numerous species including Gadus macrocephalus (Pacific cod; Cunningham et al. 2009), Oncorhynchus keta (chum salmon; Olsen et al. 2008), and Carabus solieri (beetle; Garnier et al. 2004).

Patterns of genetic structure and IBD have implications for the conservation of populations. Taylor and Dizon (1999) suggested that an important step towards effective conservation is identifying populations most impacted by anthropogenic mortality and evaluating whether enough connectivity exists to sustain those populations over time. For example, a group of populations that exhibits relatively high genetic differentiation but no IBD relationship might indicate small effective population sizes and low migration rates, suggesting that local demographic characteristics are most important in maintaining viable populations. In this case, defining management units on a smaller spatial scale to account for the demographic independence of populations could be advantageous. However, care should be taken when interpreting genetic data from heavily impacted populations. Pearse et al. (2011) found that steelhead trout (Oncorhynchus mykiss) populations in California had a historically strong IBD pattern that was erased in modern populations because of habitat fragmentation and introgression from non-local individuals. Thus, caution should be used when inferring the dispersal abilities or evolutionary history of such human-impacted populations.

Chum salmon is a species targeted by both commercial and subsistence fisheries. It is one of the most abundant Pacific salmonids and is widely distributed across the Northern Pacific Rim. Similar to other Pacific salmonids, chum salmon are anadromous and exhibit homing behavior; individuals generally return to their natal site for spawning (Tallman and Healey 1994), a trait which contributes to genetic population structure over the species range.

Chum salmon are harvested nearshore or in rivers as mixed aggregations of individuals originating from different regions, which can lead to the inadvertent overexploitation of less abundant populations (Utter and Ryman 1993). Populations from Alaska and other parts of the species range are also susceptible to interception as bycatch (i.e., the unintentional harvest of non-target organisms) by the walleye pollock (Theragra chalcogramma) fishery in the Bering Sea (Haflinger and Gruver 2009; Seeb et al. 2011b). In the past, genetic data have been used to design management actions that minimize the negative impacts of this fishery (Haflinger and Gruver 2009). Estimating the fine-scale population structure of chum salmon in Alaska is of increasing concern because of fluctuating census sizes and the uncertain effects of bycatch on specific populations (Gisclair 2009). Unstable runs of returning chum salmon not only have a deleterious effect on the commercial fishery, but also negatively impact Native Alaskan communities that depend on the species as a subsistence resource, as chum salmon are both culturally and economically important to these communities (Wolfe 2004).

Previous research on the population structure of chum salmon in Alaska has shown that the species is characterized by low genetic differentiation over large geographic areas (Seeb and Crane 1999; Seeb et al. 2011b). For example, summer-spawning chum salmon in western Alaska rivers that are thousands of $\mathrm{km}$ apart have a regional $F_{S T}$ of only 0.004 , as estimated using single nucleotide polymorphisms (SNP) (Seeb et al. 2011b). In contrast, Seeb and Crane (1999) reported relatively high genetic divergence in populations sampled from the North Alaska Peninsula and Kodiak Island, suggesting that these populations have unique evolutionary histories.

In this study we examined the genetic structure of chum salmon populations spawning in this unusually divergent region (the Alaska Peninsula and Kodiak Island) to better understand the factors influencing and maintaining genetic diversity in the species. We conducted fine-scale sampling, collecting specimens from 66 spawning locations distributed along approximately $1,300 \mathrm{~km}$ of coastline, in order to investigate regional patterns of IBD with very high spatial resolution. Spawning habitats in the region are for the most part not impacted by anthropogenic environmental degradation, and metapopulations are relatively intact. Our study area included diverse spawning habitats, including braided river systems on the North Alaska Peninsula, and glacially fed streams on the South Alaska Peninsula and Kodiak Island. We explored regional patterns of population structure and IBD using 90 nuclear and 3 mitochondrial SNPs. We hypothesized that IBD would be present because chum salmon spawn in coastal rivers that are distributed along a linear array and gene flow is spatially restricted due to homing. Evidence of population structure and IBD were found throughout the region. In addition, analyses identified outlier populations to regional IBD patterns, suggesting that populations of chum salmon in southwestern Alaska are likely influenced by the region's glacial history.

\section{Materials and methods}

Samples were collected from 1992 to 2010 by the Alaska Department of Fish and Game. Approximately 95 individuals (per collection and year) were sampled at each of 66 


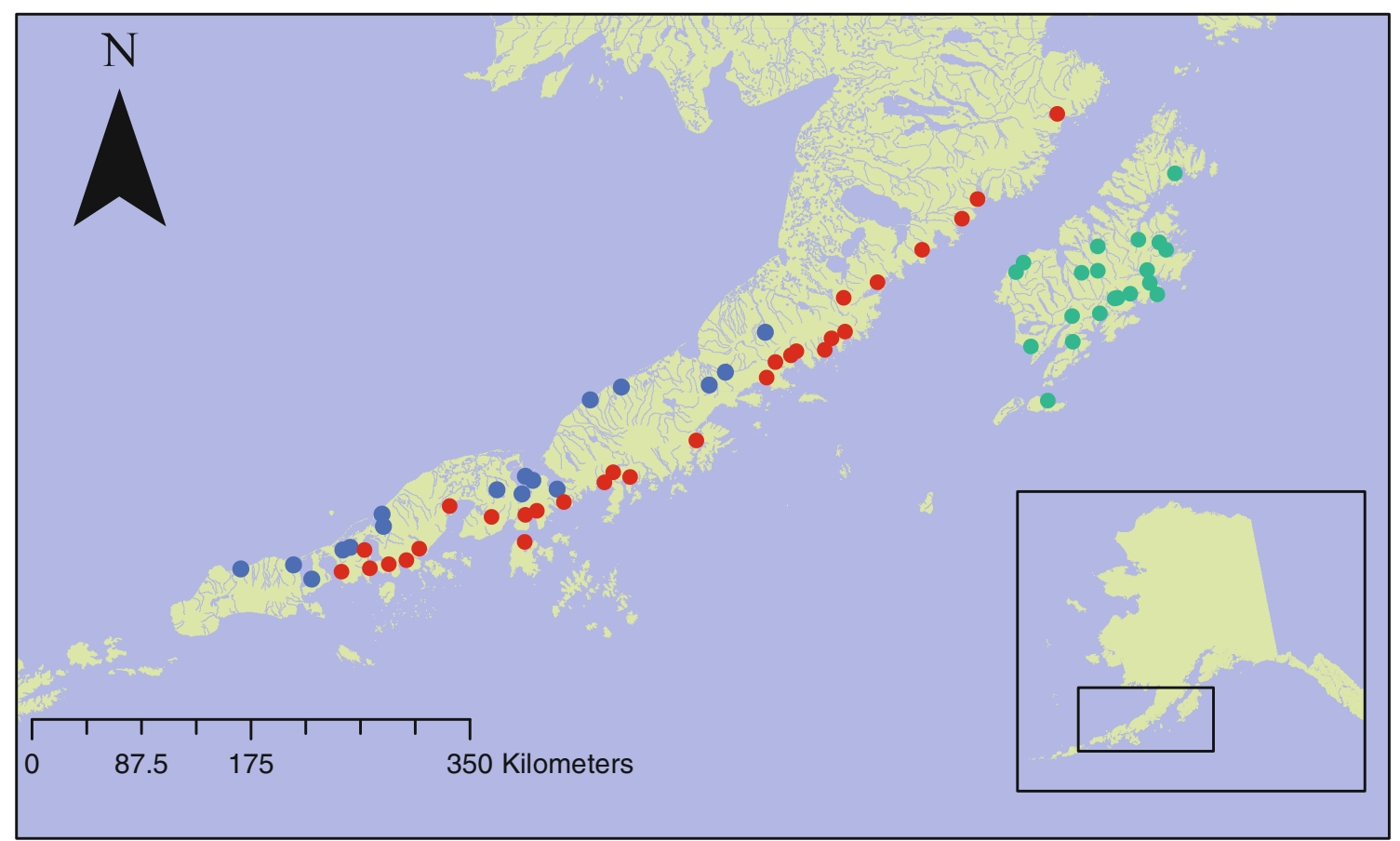

Fig. 1 Map of sampling locations. Populations collected from the North Alaska Peninsula $(n=17)$ are in blue, South Alaska Peninsula populations $(n=29)$ are in red, and Kodiak Island populations $(n=20)$ are in green

locations on the Alaska Peninsula and Kodiak Island that likely represent distinct breeding populations (Fig. 1). Temporal replicates of each sampling location were collected when possible, resulting in 105 total collections (Table 1). From 1992 to 2002, salmon were captured by beach seine, and heart or liver tissue was collected and frozen in liquid nitrogen until transferred to long-term storage at $-80{ }^{\circ} \mathrm{C}$. From 2008 onward, individual salmon were captured by beach seine, held momentarily while the axillary process on the ventral fin was removed, and subsequently released. Axillary processes were stored in $95 \%$ ethanol.

DNA was extracted from 8,240 individuals using the DNeasy 96 Tissue Kit (QIAGEN, Valencia, CA, USA). A total of 96 SNPs (Online Resource 1) was assayed using $5^{\prime}$ nuclease reactions (Seeb et al. 2009) on the Fluidigm 96.96 Dynamic Array (Fluidigm, San Francisco, CA, USA). As a quality control measure, approximately eight individuals from each population were re-extracted and genotyped at all loci to ensure that genotypes were accurate and reproducible.

We tested for homogeneous allele frequencies in collections from a single location that were sampled in different years using a $\chi^{2}$ test in the program CHIFISH (Ryman 2006). If no statistically significant difference $(\alpha=0.01)$ over all loci was found between collection years, individuals sampled from the same geographic location were pooled (Table 1) to achieve a larger sample size as recommended by Waples (1990).

Allele frequencies and heterozygosity were calculated in GENALEX 6.4 (Peakall and Smouse 2006). Deviations from
Hardy-Weinberg equilibrium (HWE) in each population were detected using a $\chi^{2}$ test $(\alpha=0.05)$ in GENALEX 6.4. Patterns of linkage equilibria within populations were examined for all locus pairs using exact tests in GENEPOP 4.0 (Raymond and Rousset 1995; Rousset 2008). We compared patterns of linkage disequilibrium in each population by calculating the statistic $R^{2}$ that describes the overall correlation coefficient averaged across multiple loci and alleles. The calculations were done with the program LDNE (Waples and Do 2008), and $R^{2}$ was subsequently used to estimate the effective population size $\left(N_{e}\right)$ of each sample collection.

Pairwise genetic differentiation $\left(F_{S T}\right)$ between all populations (Weir and Cockerham 1984) was estimated in GENEPOP 4.0. Statistical significance of population differentiation was evaluated using 1,000 permutations in ARLEQUIN 3.5 (Excoffier and Lischer 2010). Patterns of population differentiation were further explored with correspondence analysis based on genotypes using the ADEGENET package (Jombart 2008) in R (R Core Team 2013). Subsequently, we explored whether pairwise genetic differentiation was positively correlated with the geographic distance separating populations. The shortest waterway distance between sampling locations was estimated using a least cost path analysis in ARCGIS ver. 10 (ESRI, Inc). Linearized $F_{S T}$ estimates $\left(F_{S T} /\left(1-F_{S T}\right)\right)$ were regressed to waterway distance (Rousset 1997), and statistical significance was evaluated based on least squares regression in $\mathrm{R}$, as in Koizumi et al. (2006). Hellberg (1994) has shown that for pairwise data, $p$ values are almost identical between Mantel 
Table 1 Sampling locations and associated collection information. Population groupings (North Alaska Peninsula, South Alaska Peninsula, and Kodiak Island) correspond to map colors on Fig. 1. $N_{e}$ was estimated using the program LDNE (Waples and Do 2008)

\begin{tabular}{|c|c|c|c|c|c|c|}
\hline Pop\# & Location & Collection dates & Latitude & Longitude & $n$ & $N_{e}$ \\
\hline \multicolumn{7}{|c|}{ North Alaska Peninsula } \\
\hline 1 & Wiggly Creek & 08/04/1993, 08/13/2009 & 56.98 & -157.66 & 178 & 951 \\
\hline 2 & Plenty Bear Creek & 08/02/1993, 08/11/2009 & 56.71 & -158.30 & 138 & 2,939 \\
\hline 3 & Meshik River & 08/01/1992, 08/11/2009 & 56.61 & -158.50 & 172 & 1,208 \\
\hline 4 & Ilnik River & $07 / 30 / 2002$ & 56.55 & -159.64 & 49 & 486 \\
\hline 5 & Cape Seniavin & 08/28/2001, 08/16/2009, 08/2010 & 56.43 & -160.03 & 96 & 717 \\
\hline 6 & Moller Bay & 08/16/2009 & 55.78 & -160.35 & 94 & 523 \\
\hline 7 & Lawrence Valley Creek & 08/01/1992, 08/16/2009 & 55.83 & -160.66 & 190 & 547 \\
\hline 8 & Coal Valley & $08 / 27 / 2008$ & 55.85 & -160.76 & 94 & 605 \\
\hline 9 & Deer Valley & $08 / 27 / 2008$ & 55.72 & -160.79 & 91 & 2,669 \\
\hline 10 & Nelson River & 08/01/1992, 08/27/2008 & 55.73 & -161.11 & 143 & 675 \\
\hline 11 & Moffet Creek & 09/05/1996 & 55.46 & -162.51 & 95 & 1,388 \\
\hline 12 & Joshua Green & 08/18/2009 & 55.37 & -162.47 & 92 & 2,659 \\
\hline 13 & Frosty Creek & 09/01/1992, 08/20/2009 & 55.19 & -162.86 & 189 & 1,226 \\
\hline 14 & Alligator Hole & 09/04/1996, 08/20/2009 & 55.16 & -162.94 & 183 & 1,385 \\
\hline 15 & Trader's Cove & 08/01/1992 & 54.93 & -163.28 & 75 & 197 \\
\hline 16 & St. Catherine Cove & 08/19/2009 & 55.01 & -163.53 & 93 & 262 \\
\hline 17 & Peterson Lagoon & 08/01/1992, 08/19/2009 & 54.93 & -164.17 & 180 & 449 \\
\hline \multicolumn{7}{|c|}{ South Alaska Peninsula } \\
\hline 18 & Little John Lagoon & 08/01/1992, 08/19/2009 & 55.01 & -162.91 & 172 & 1,213 \\
\hline 19 & Sandy Cove & 08/26/1996, 08/20/2009 & 55.14 & -163.04 & 188 & 707 \\
\hline 20 & Russell Creek & 08/30/1993, 08/20/2009 & 55.19 & -162.68 & 187 & 2,144 \\
\hline 21 & Delta Creek & 08/29/1996 & 55.11 & -162.35 & 94 & 831 \\
\hline 22 & Belkovski River & 08/01/1992 & 55.15 & -162.14 & 87 & 203 \\
\hline 23 & Volcano Bay & $08 / 15 / 2009$ & 55.24 & -162.00 & 95 & 653 \\
\hline 24 & Ruby's Lagoon & 08/31/1996 & 55.57 & -161.68 & 92 & 331 \\
\hline 25 & Canoe Bay & 08/01/1992, 08/15/2009 & 55.53 & -161.14 & 181 & 4,107 \\
\hline 26 & Zachary Bay & $8 / 13 / 1992$ & 55.38 & -160.69 & 77 & 396 \\
\hline 27 & Foster Creek & 08/20/1992, 08/14/2009 & 55.57 & -160.72 & 181 & 464 \\
\hline 28 & Coleman Creek & 09/06/1996 & 55.61 & -160.57 & 95 & 7,443 \\
\hline 29 & Chichagof Bay & $08 / 17 / 2009$ & 55.69 & -160.24 & 92 & 211 \\
\hline 30 & Big River & $08 / 17 / 2009$ & 55.86 & -159.75 & 94 & 406 \\
\hline 31 & Stepovak River & 08/18/1992, 08/17/2009 & 55.93 & -159.65 & 144 & 192 \\
\hline 32 & Ivanof River & 08/23/1993, 08/14/2009 & 55.91 & -159.43 & 181 & 907 \\
\hline 33 & Portage Creek & $8 / 21 / 1993$ & 56.20 & -158.62 & 95 & 1,053 \\
\hline 34 & Kujulik Bay & $08 / 22 / 1993,08 / 12 / 2009$ & 56.68 & -157.76 & 163 & 521 \\
\hline 35 & Aniakchak River & $8 / 3 / 1993$ & 56.80 & -157.66 & 94 & 4,566 \\
\hline 36 & Amber Bay & $08 / 12 / 2009$ & 56.86 & -157.46 & 85 & 433 \\
\hline 37 & Northeast Creek & $08 / 23 / 2008$ & 56.88 & -157.39 & 94 & 8,867 \\
\hline 38 & Ocean Bay & 08/13/2009 & 56.91 & -157.02 & 79 & 442 \\
\hline 39 & Nakililok River & $08 / 23 / 2008$ & 56.99 & -156.94 & 95 & 756 \\
\hline 40 & Chiginigak Bay River & 08/20/1993, 08/12/2009 & 57.04 & -156.76 & 160 & 465 \\
\hline 41 & Kialagvik River & 08/11/1993, 08/25/2009 & 57.28 & -156.80 & 178 & 1,088 \\
\hline 42 & Pass Creek & $08 / 24 / 2009$ & 57.40 & -156.36 & 94 & 592 \\
\hline 43 & Dry Bay River & $08 / 24 / 2009$ & 57.64 & -155.78 & 71 & 300 \\
\hline
\end{tabular}


Table 1 continued

\begin{tabular}{lllrrrr}
\hline Pop\# & Location & Collection dates & Latitude & Longitude & $n$ & $N_{e}$ \\
\hline 44 & Bear Bay Creek & $08 / 11 / 1993,08 / 19 / 2009$ & 57.87 & -155.25 & 188 \\
45 & Alagogshak River & $08 / 12 / 1993$ & 58.02 & -155.04 & 94 \\
46 & Big River, Hallo Bay & $09 / 02 / 2009$ & 58.63 & -153.96 & 95 & 385
\end{tabular}

Kodiak Island

\begin{tabular}{|c|c|c|c|c|c|c|}
\hline 47 & Karluk Lagoon & $08 / 31 / 2009$ & 57.57 & -154.42 & 84 & 54 \\
\hline 48 & Sturgeon River & 07/01/1992, 07/10/2009 & 57.50 & -154.51 & 158 & 684 \\
\hline 49 & Big Sukhoi & 08/01/1992, 08/07/2009 & 56.97 & -154.31 & 190 & 17,789 \\
\hline 50 & Deadman River & $08 / 18 / 2009$ & 57.18 & -153.77 & 95 & 401 \\
\hline 51 & Sitkinak Island & 08/07/2009 & 56.58 & -154.09 & 93 & 148 \\
\hline 52 & Northeast Portage & $08 / 18 / 2009$ & 57.00 & -153.76 & 94 & 1,707 \\
\hline 53 & Barling Bay Creek & 08/06/2009 & 57.20 & -153.40 & 93 & 490 \\
\hline 54 & West Kiliuda Creek & $09 / 12 / 2009$ & 57.31 & -153.20 & 83 & 777 \\
\hline 55 & Dog Bay & 08/01/1992 & 57.31 & -153.16 & 95 & 612 \\
\hline 56 & Coxcomb Creek & $08 / 17 / 2009$ & 57.34 & -153.00 & 90 & 334 \\
\hline 57 & Gull Cape Lagoon & 09/14/1993, 09/23/2009 & 57.33 & -152.64 & 186 & 324 \\
\hline 58 & Eagle Harbor & $08 / 17 / 2009$ & 57.42 & -152.73 & 95 & 165 \\
\hline 59 & Rough Creek & $09 / 12 / 2009$ & 57.51 & -152.77 & 76 & 628 \\
\hline 60 & American River & 09/01/1992 & 57.65 & -152.51 & 94 & 2,006 \\
\hline 61 & Russian River & 08/17/2007, 08/17/2009 & 57.70 & -152.59 & 185 & 547 \\
\hline 62 & Kizhuyak River & 08/01/1992, 08/19/2009 & 57.72 & -152.88 & 175 & 542 \\
\hline 63 & Uganik River & 08/01/1992, 08/20/2009 & 57.68 & -153.42 & 175 & 943 \\
\hline 64 & Spiridon River-Upper & 08/18/2009 & 57.51 & -153.42 & 89 & 1,307 \\
\hline 65 & Zachar River & $07 / 21 / 2009$ & 57.49 & -153.64 & 66 & 521 \\
\hline 66 & Kitoi Bay Hatchery & $07 / 23 / 1993,07 / 29 / 2009$ & 58.19 & -152.37 & 192 & 373 \\
\hline
\end{tabular}

tests and ordinary least squares regression with degrees of freedom designated by the number of populations. Ordinary least squares regression was conducted first with all populations considered together. Subsequently, each geographic region (North Alaska Peninsula, South Alaska Peninsula, and Kodiak Island) was analyzed separately so that regional IBD patterns could be further examined.

Putative outlier populations from regional (North Alaska Peninsula, South Alaska Peninsula, and Kodiak Island) IBD patterns were identified by examining the mean regression residual for each population. If a population was divergent from regional IBD patterns, then its regression residuals were more biased towards values different from zero than populations following regional IBD patterns. Following the decomposed pairwise regression analysis (DPRA) method of Koizumi et al. (2006), we sequentially removed populations from the analysis when $95 \%$ confidence intervals of the mean residual did not include zero. The fit of IBD models considering different putative outlier populations was evaluated using Akaike's information criteria (AIC, Burnham and Anderson 2002). AIC was calculated as $A I C=2 K+n \ln (R S S / n)$, where $K$ is the number of parameters (in this case the only parameter is waterway distance), $n$ is the number of populations, and $R S S$ is the residual sum of squares (Koizumi et al. 2006). Corrected $A I C\left(A I C_{C}\right)$ was used because of small sample sizes $(n / K<40)$. Models were considered equally likely if the difference in $A I C_{C}$ values $(\triangle A I C)$ was less than two.

Finally, the effect of $N_{e}$ on within-region genetic differentiation was investigated. We expected that populations with small $N_{e}$ would show relatively high levels of differentiation due to genetic drift. The correlation between genetic differentiation and effective population size was evaluated by regressing $1 / N_{e}$ against mean population $F_{S T}$ for all withinregion comparisons (North Alaska Peninsula, South Alaska Peninsula, and Kodiak Island), and statistical significance was evaluated using least squares regression in $\mathrm{R}$.

\section{Results}

SNP genotyping and population statistics

A few individuals were missing more than $15 \%$ of genotypes (suggesting poor quality DNA) and were removed from the data set, leaving 8,103 individuals for the remaining 
analyses. Quality control analysis showed that only $0.05 \%$ of the genotypes contained discrepancies between the original genotypes and the re-extracted samples, indicating that our genotypes were reproducible and accurate.

No significant differentiation across all loci was found for samples collected from the same geographic location in different years, so temporal replicates were pooled as indicated in Table 1. Two populations, St. Catherine's Cove $(p=0.02)$ and Sturgeon River $(p=0.002)$ exhibited significantly more deviations from HWE than would be expected by chance alone. These deviations from HWE were not localized in any one SNP, so we did not remove any locus from our analysis.

We tested for linkage disequilibrium by conducting tests between all possible pairs of nuclear SNPs and found 14,246 (5\%) to be statistically significant at $\alpha=0.05$. Three SNP



First axis: $22 \%$ variation

North Alaska Peninsula

South Alaska Peninsula

Kodiak Island

Fig. 2 Correspondence analysis using population data. Each dot represents a population and color indicates the population number as in Table 1. A Analysis using 93 nuclear SNPs and the composite mtDNA haplotype. The arrow is a schematic representation of differentiation driven by the mtDNA composite haplotype. Three populations, Little John Lagoon (18), Sandy Cove (19), and Delta Creek (21), contain an alternative mtDNA haplotype. B Little John Lagoon, Sandy Cove, and Delta Creek populations appear similar to adjacent populations when only nuclear SNPs are considered. Highly pairs (Oke_gdh-162 and Oke_gdh-191;Oke_pgap-92 and Oke_pgap-111; Oke_U1021-102 and Oke_1022-139) were found to be in linkage disequilibrium in almost all of the populations. We retained only one locus from each pair based on highest global $F_{S T}$ (Online Resource 1) for the remainder of the analyses to avoid redundant data. Patterns of linkage disequilibrium within populations varied. The Karluk Lagoon population (47) exhibited many more deviations from linkage equilibrium than expected by chance alone $(p<0.0001)$. Consequently, Karluk Lagoon had an estimated $N_{e}=54$, the smallest of any population.

We estimated a global $F_{S T}$ of 0.04 . In comparisons between populations, pairwise $F_{S T}$ values ranged from 0.00 to 0.19 . Correspondence analysis of genotypic data allowed us to visualize population differentiation (Fig. 2a, b). Five populations appeared to be highly divergent (18-Little John

B
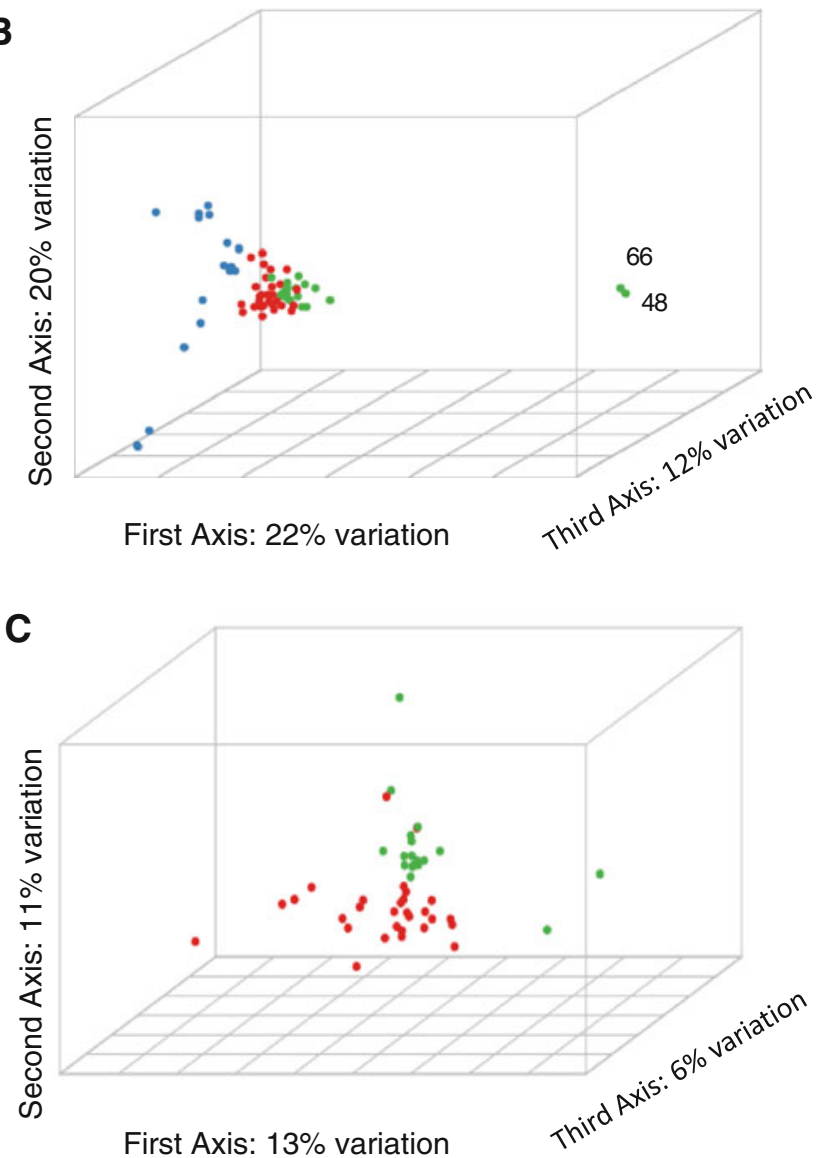

differentiated North Alaska Peninsula populations are depicted in dark blue, while the Sturgeon River (48) and Kitoi Bay Hatchery (66) populations are found at the far right of the plot. C Populations from the South Alaska Peninsula and Kodiak Island are modestly differentiated from each other along the first and third axes when analyzed with 93 nuclear SNPs. The Sturgeon River and Kitoi Bay Hatchery populations were excluded from this plot because of their unique and high differentiation from all other populations 
Lagoon, 19-Sandy Cove, 21-Delta Creek, 48-Sturgeon River, and 66-Kitoi Bay Hatchery) from all others. In addition, populations from the North Alaska Peninsula were differentiated from each other, while populations from the South Alaska Peninsula and Kodiak Island clustered together.

When SNPs from both nuclear DNA and mtDNA were considered, $22 \%$ of the variation in the data set was explained by the first axis and was driven by differences in mtDNA haplotypes (Fig. 2a). MtDNA frequencies had a divergent pattern; all but three populations (18-Little John Lagoon, 19-Sandy Cove, and 21-Delta Creek) were monomorphic at the composite mtDNA SNP. These three populations, originating from the South Alaska Peninsula, had an alternative haplotype at a frequency greater than 0.25 but were not differentiated when only nuclear SNP loci were considered (Fig. 2b).

Isolation by distance and decomposed pairwise regression analysis

A search for metapopulation structure involved the common consideration of all populations followed by analyses within the three regions-North Alaska Peninsula, South Alaska Peninsula, and Kodiak Island. The partitioning of populations by geographic region was supported by correspondence analyses (Fig. 2b, c). Initial IBD estimates were refined by sequential removal of outlier populations indicated by decomposed pairwise regression analyses. IBD was first examined for all populations, and very weak correlation between genetic and waterway distance was found (Fig. 3, $R^{2}=0.06, p<0.0001$ ). Poor fit of the IBD model to the data was driven by two populations with very high genetic differentiation: the Sturgeon River (48) and Kitoi Bay Hatchery (66) populations. When these populations were removed, we observed higher correlation between genetic and waterway distance (Fig. $3, R^{2}=0.17$, $p<0.0001)$.

Decomposed pairwise regression analysis identified nine populations that were outliers from their respective regional (South Alaska Peninsula and Kodiak Island) IBD patterns: Sandy Cove (19), Ruby's Lagoon (24), Zachary Bay (26), Karluk Lagoon (47), Sturgeon River (48), Big Sukhoi (49), Sitkinak Island (51), Gull Cape Lagoon (57), and Kitoi Bay Hatchery (66). In all cases, fit of the IBD model to data improved when outlier populations were removed from each region, as indicated by $R^{2}$ and $\triangle A I C$ values (Table 2).

Populations partitioned by geographic region (North Alaska Peninsula, South Alaska Peninsula, and Kodiak Island) had very different patterns of regional IBD (Fig. 4). The North Alaska Peninsula contained highly differentiated populations that conformed to IBD (slope $=1 \times 10^{-4}$, $\left.R^{2}=0.52, p<0.0001\right)$. However, variance in $F_{S T}$ values was high and variance suddenly increased at pairwise population distances greater than $100 \mathrm{~km}$ (Fig. 5a). This indicates that populations on the North Alaska Peninsula show a strong but non-linear pattern of increasing genetic differentiation with distance.

Populations from the South Alaska Peninsula were less differentiated than populations from the North Alaska Peninsula (Fig. 4). Decomposed pairwise regression analysis identified three outlier populations on the South Alaska Peninsula (Table 2). When these populations were removed from the data set, there was a stronger correlation between genetic and waterway distance (slope $=8 \times 10^{-6}, R^{2}=$ $0.08, p<0.0001$ ). IBD slope on the South Alaska Peninsula was an order of magnitude smaller than on the North Alaska Peninsula, and we observed relatively large variance in $F_{S T}$ over both small and large pairwise geographic distances (Fig. 5b).
Fig. 3 Linear regression of waterway to genetic distance including all populations is represented by the black line and accompanying equation. Black triangles represent pairwise comparisons between the Sturgeon River and Kitoi Bay Hatchery to all other populations

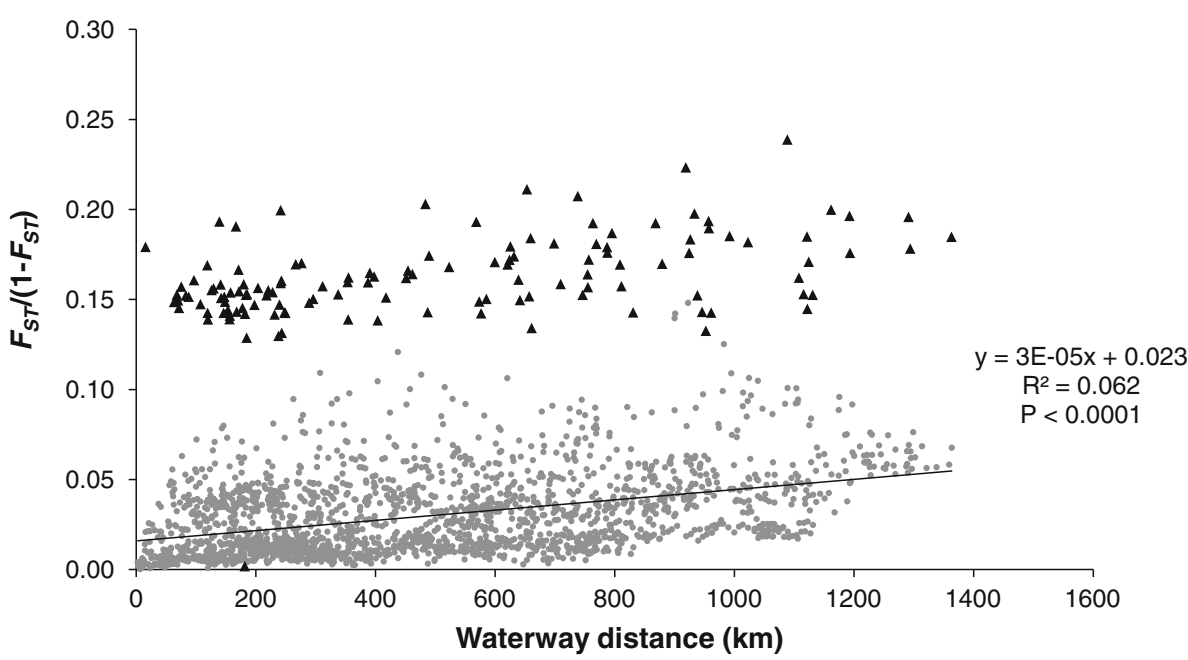


Table 2 Fit of alternative IBD models in each geographic region with different outlier populations excluded from the analysis

\begin{tabular}{|c|c|c|c|c|c|c|c|c|}
\hline Population excluded & $\mathrm{n}$ & $\mathrm{K}$ & $\mathrm{R}^{2}$ & Intercept $\times 10^{2}$ & Slope $\times 10^{2}$ & $p$ value & $\mathrm{AICc}$ & $\Delta \mathrm{AICc}$ \\
\hline \multicolumn{9}{|l|}{ North Alaska Peninsula } \\
\hline 10 & 16 & 1 & 0.517 & 0.926 & 0.012 & $<0.0001$ & -101 & 1 \\
\hline None & 17 & 1 & 0.394 & 1.350 & 0.011 & $<0.0001$ & -100 & \\
\hline \multicolumn{9}{|l|}{ South Alaska Peninsula } \\
\hline $24,26,19$ & 26 & 1 & 0.084 & 0.892 & 0.001 & $<0.0001$ & -211 & 10 \\
\hline 24,26 & 27 & 1 & 0.086 & 0.926 & 0.001 & $<0.0001$ & -200 & 7 \\
\hline 24 & 28 & 1 & 0.034 & 1.141 & 0.001 & 0.0003 & -194 & 9 \\
\hline None & 29 & 1 & 0.015 & 1.361 & 0.001 & 0.0132 & -185 & \\
\hline \multicolumn{9}{|l|}{ Kodiak Island } \\
\hline $66,48,47,51,49,57$ & 14 & 1 & 0.485 & 0.274 & 0.004 & $<0.0001$ & -131 & 14 \\
\hline $66,48,47,51,49$ & 15 & 1 & 0.095 & 0.709 & 0.003 & 0.0013 & -117 & 8 \\
\hline $66,48,47,51$ & 16 & 1 & 0.046 & 0.987 & 0.003 & 0.0187 & -109 & 2 \\
\hline $66,48,47$ & 17 & 1 & 0.024 & 1.347 & 0.003 & 0.0746 & -108 & 0 \\
\hline 66,48 & 18 & 1 & 0.024 & 1.555 & 0.003 & 0.0542 & -108 & 32 \\
\hline 66 & 19 & 1 & 0.007 & 2.672 & 0.005 & 0.2605 & -76 & 7 \\
\hline None & 20 & 1 & 0.009 & 3.490 & 0.007 & 0.1847 & -69 & \\
\hline
\end{tabular}

The number of populations in the analysis is indicated by $n, K$ is the number of parameters, $R^{2}$ is from the linear regression of linear $F_{S T}$ to waterway distance, $p$ values are from a least squares regression, and AIC is calculated as in Koizumi et al. (2006)

Fig. 4 Regression of waterway to genetic distance with geographic region. Populations identified as regional outliers by decomposed pairwise regression analysis are excluded populations partitioned by

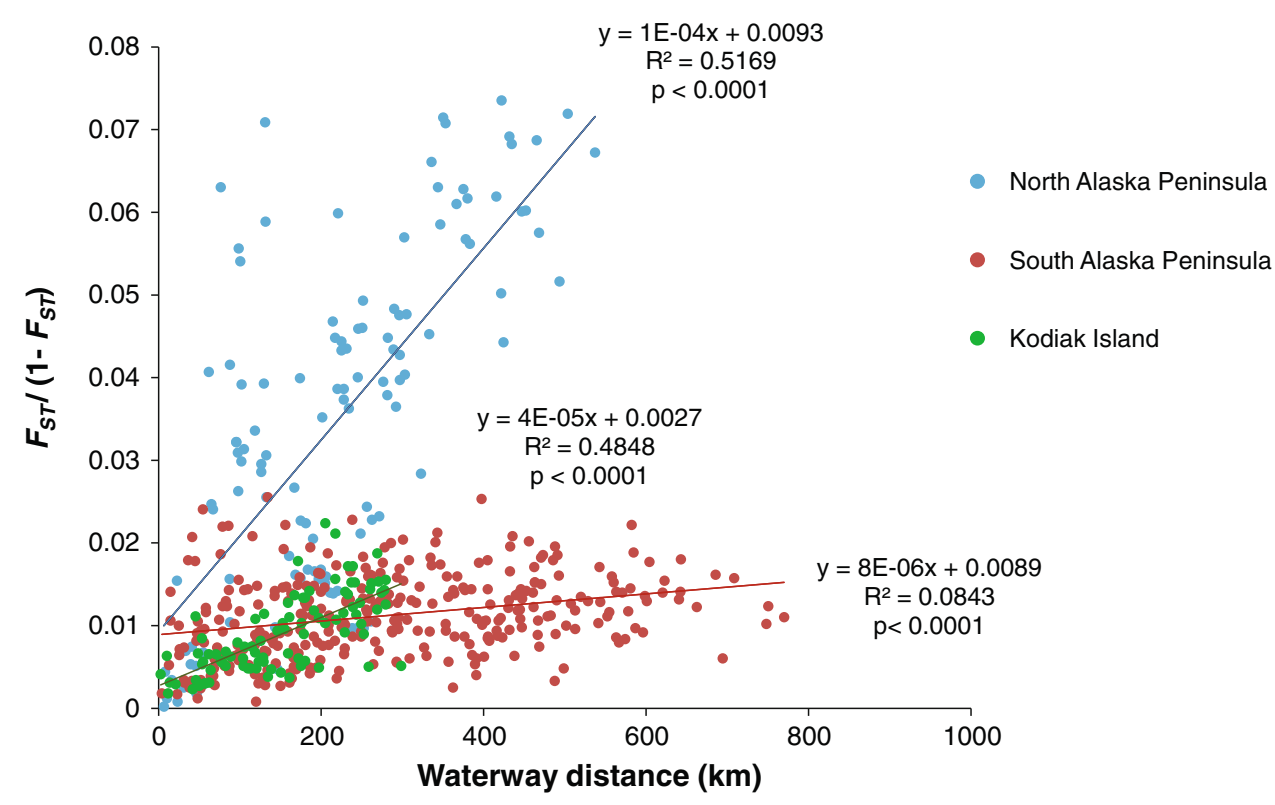

Kodiak Island contained genetically diverse populations, despite the small geographic extent of the region. We found evidence of two highly differentiated populations in this area, the Sturgeon River (48) and Kitoi Bay Hatchery (66) (Fig. 2b). Mean pairwise population $F_{S T}$ for these populations was 0.13 and 0.14 , respectively. Decomposed pairwise regression analysis identified six outlier populations on Kodiak Island in total (Table 2). Correlation between genetic and waterway distance increased when outlier populations were removed from the dataset, and relatively strong IBD was observed (Fig. 4; slope $=4 \times$ $\left.10^{-5}, R^{2}=0.48, p<0.0001\right)$.

Estimated effective population sizes $\left(N_{e}\right)$ ranged from 54 to 17,789 , and the median value of $N_{e}$ over all populations was 609 (Table 1). We tested the hypothesis that populations with small $N_{e}$ are outliers from regional IBD patterns by regressing the inverse of effective population size $\left(1 / N_{e}\right)$ to mean population $F_{S T}$ in each region. On the North Alaska Peninsula there was no correlation between these two quantities $\left(R^{2}=6 \times 10^{-5}, p=0.98\right)$; similarly, 

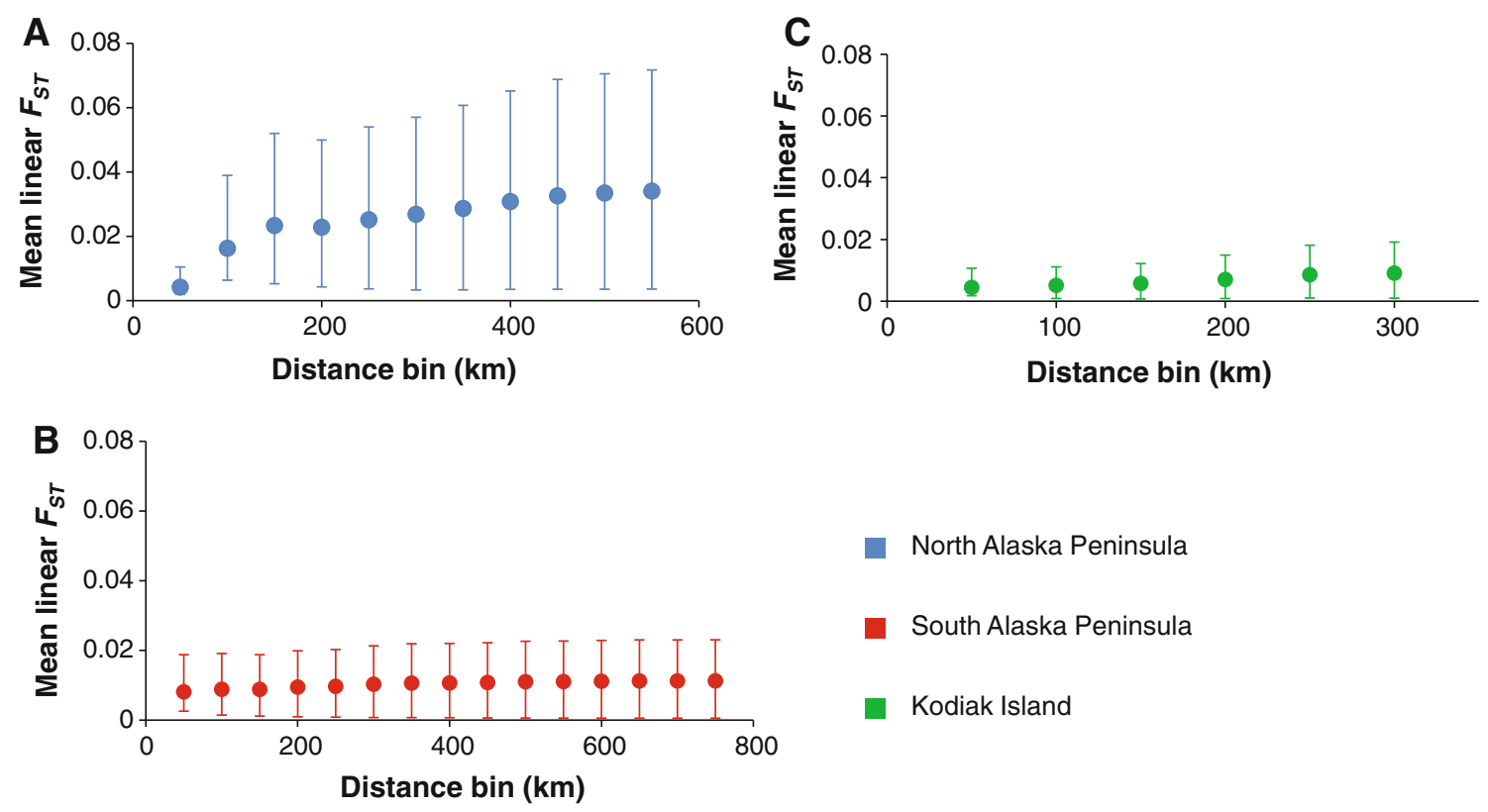

North Alaska Peninsula

South Alaska Peninsula

Kodiak Island

Fig. 5 Mean $F_{S T}$ with $95 \%$ confidence intervals at increasing spatial scales for populations from the A North Alaska Peninsula, B South Alaska Peninsula, and $\mathbf{C}$ Kodiak Island

no correlation was found on the South Alaska Peninsula $\left(R^{2}=0.05, p=0.24\right)$ and Kodiak Island $\left(R^{2}=0.001\right.$, $p=0.83)$.

\section{Discussion}

The purpose of this study was to investigate the fine-scale population structure of chum salmon and better understand the factors influencing and maintaining genetic diversity in the species. We found very different patterns of differentiation and IBD depending on the region examined, suggesting that chum salmon in southwestern Alaska are influenced by diverse evolutionary and/or demographic histories.

Theoretical models describing IBD are well established (Wright 1943; Rousset 1997; Slatkin 1993), and the simplest models assume a linear array of populations of finite size that do not experience selection; migration occurs between adjacent populations and is described by the number of reproductively successful migrants exchanged between populations in each generation. This value is the product of the effective population size $\left(N_{e}\right)$ and the proportion of each population that are reproducing migrants $(m)$. Over time, these idealized populations are expected to reach equilibrium between migration and genetic drift. In this case, there is a linear relationship between pairwise genetic and geographic distances.

Patterns of IBD depend on the spatial arrangement of populations, the magnitude of gene flow between populations, and the time since gene flow began. In a one-dimensional array of ideal populations (equal size, equal migration rates, no selection), the area over which IBD is present depends on the equation $\sqrt{2 N m \tau}$, where $\tau=$ time, $m=$ migration rate, and $N=$ effective population size (Slatkin 1993). In this case, patterns of IBD form first between adjacent populations (Kimura and Weiss 1964), and extend over larger spatial scales with the passage of time. Unequal gene flow between populations, natural selection, and historical events (e.g. bottlenecks, sudden range expansions) are examples of processes that may inhibit populations from establishing IBD.

IBD was initially explored using all populations, and very weak correlation (Fig. 3) between genetic and waterway distance was found due to the presence of highly differentiated Sturgeon River (48) and Kitoi Bay Hatchery (66) populations (mean pairwise $F_{S T}=0.13$ and 0.14 , respectively). The Kitoi Bay Hatchery chum salmon population was founded in 1980 with gametes originating from Sturgeon River individuals (Musslewhite 2011), and today the two populations are not significantly different at the genetic markers used in this study $\left(F_{S T}=0.001, p=0.99\right)$. However, Karluk Lagoon salmon (collected only 15 waterway $\mathrm{km}$ from the Sturgeon River) were highly differentiated from the Sturgeon River population $\left(F_{S T}=0.18\right)$. The Karluk Lagoon population more closely resembles other Kodiak Island populations, suggesting that these populations originated from the same genetic lineage. The high genetic differentiation between Sturgeon River salmon and other spatially proximate populations of chum salmon on Kodiak 
Island is extremely unusual for the species (Seeb et al. 2011b).

A previous study (Seeb and Crane 1999) using allozymes reported similar high genetic divergence between the Sturgeon River and other populations, and this pattern was attributed to the glacial history of southwestern Alaska. During the Last Glacial Maximum, circa 25,000 years ago, the majority of the southwestern Alaska coast was covered by the Cordilleran Ice Sheet (Clark et al. 2009), making the region inhospitable to anadromous fish. However, geological evidence suggests that the southwest portion of Kodiak Island remained ice-free (Karlstrom and Ball 1969; Mann and Peteet 1994; Mann and Hamilton 1995), possibly providing a refugium for aquatic species in proglacial lakes (Karlstrom and Ball 1969). The Sturgeon River drainage is found in the part of southwest Kodiak Island that remained unglaciated during the Last Glacial Maximum (Fig. 6).

The Sturgeon River population has likely coexisted on Kodiak Island with other populations for hundreds of generations. If straying and gene flow between proximate spawning sites has occurred, why do we detect such unusually high genetic differentiation today? One possibility is that not enough generations have passed since gene flow to adjacent populations began, and differences will continue to erode over time. A second possibility is that an environmental barrier to gene flow exists between the Sturgeon River (and Kitoi Bay Hatchery) and other populations. However, we are not aware of any significant geographic features (such as a waterfall or dam) that could bar migration to and from the Sturgeon River.

Previous research has shown that temporal differences in reproductive date can be a barrier to gene flow, a phenomenon known as "isolation by time" (Hendry and Day 2005). Multiple studies on salmonids indicate that populations with

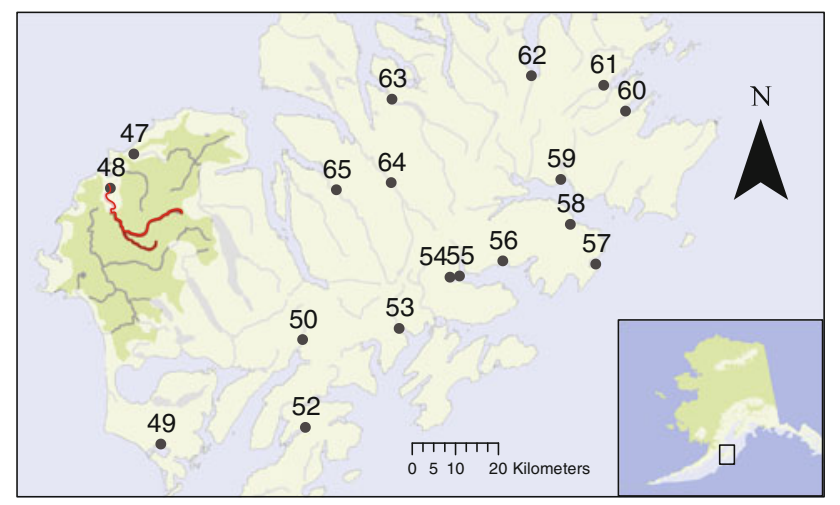

Fig. 6 Sampling locations on Kodiak Island; numbers correspond to locations from Table 1. Transparent white overlay represents the Cordilleran Ice Sheet circa 25,000 years ago. The ice free refugium in southwest Kodiak Island is discernible in green, and the present-day hydrography of the Sturgeon River is indicated in red different spawning dates are genetically differentiated, even when individuals spawn in proximate locations (reviewed in Hendry and Day 2005). Sturgeon River (and Kitoi Bay Hatchery) chum salmon are characterized by different migration timing and begin to arrive in freshwater in midJune; in contrast, other Kodiak Island spawning populations enter rivers in mid-to-late July (Faustini 1999). Thus, it is possible that contemporary gene flow between the Sturgeon River and other populations is restricted by differences in spawning date similar to that observed for summer chum from Puget Sound and the Strait of Juan de Fuca, in the Pacific Northwest of North America (Phelps et al. 1994). However, it is unlikely that these differences in spawning date are the sole cause of the observed genetic differentiation, as the magnitude of divergence between the Sturgeon River (and Kitoi Bay Hatchery) and other populations is much greater than other spatially proximate but temporally isolated populations of chum salmon (Seeb and Crane 1999). Instead, this pattern is similar to the strongly diverged, sympatric populations of Chinook salmon $(O$. tshawytscha) in the upper Columbia River that migrate to freshwater either in the fall or spring; it was suggested that the large genetic differences between Chinook salmon populations in this region are the result of secondary contact rather than sympatric evolutionary divergence (Waples et al. 2004).

Previous research has shown that population-level diversity of life history characteristics (such as spawn timing) within commercially exploited sockeye salmon contributes to productive and relatively stable fisheries (Hilborn et al. 2003). In addition, diversity in spawn timing provides salmon-derived nutrients to aquatic food webs over long periods of time (Schindler et al. 2010). The Sturgeon River population is unique in our study region because of its early spawning date, and it is known to provide an important source of protein to Kodiak bears and other predators early in the summer (Barnes 1990). Our research has confirmed that it is also highly genetically differentiated from other populations in the region and can be considered a potentially important reservoir of genetic and life history diversity for Alaska chum salmon.

Identifying outlier populations with decomposed pairwise regression analysis

Previous studies (Koizumi et al. 2006; Taylor et al. 2003) have shown that the inclusion of a few highly divergent populations ("outliers") can obscure regional IBD patterns because this relationship is evaluated using pairwise population data. Fit of the IBD model to the data improved when the Sturgeon River and Kitoi Bay Hatchery populations were removed from the analysis. However, we also found that the magnitude of genetic differentiation varied 
by region; when the IBD slope was calculated with populations from the North Alaska Peninsula, it was an order of magnitude larger than the IBD slope estimated from South Alaska Peninsula populations, an unanticipated pattern since the geographic extent of the sampling area was similar. Therefore, we partitioned the populations by geographic region of origin (North Alaska Peninsula, South Alaska Peninsula, and Kodiak Island), used decomposed pairwise regression analysis to identify outlier populations, and examined IBD within each region. Decomposed pairwise regression analysis of genetic and waterway distances revealed nine outlier populations that did not conform to regional IBD patterns (South Alaska Peninsula: Sandy Cove-19, Ruby's Lagoon-24, Zachary Bay-26; Kodiak Island: Karluk Lagoon-47, Sturgeon River-48, Big Sukhoi49, Sitkinak Island-51, Gull Cape Lagoon-57, Kitoi Bay Hatchery-66); fit of regional IBD models to the data improved when outlier populations were removed based on $R^{2}$ and $\triangle A I C$ scores (Table 2).

Theoretical population genetics indicates that populations with small effective population size experience more genetic drift than large populations (Wright 1931). In a one-dimensional system, a small population might be an outlier from regional IBD if genetic drift has a much greater effect than gene flow on allele frequencies (case III in Hutchison and Templeton 1999). We tested the hypothesis that populations with small effective population size are outliers to regional IBD patterns and did not find a statistically significant correlation between small $N_{e}$ and high mean $F_{S T}$. These results suggest that small effective population sizes may not be the major cause of higher than expected genetic differentiation and lack of IBD between proximate populations; instead, other factors likely affect gene flow and population divergence in each region.

Previous studies have indicated that landscape heterogeneity can influence migration and IBD patterns (Coulon et al. 2004). Gene flow in the American marten (Martes americana), for example, is constrained by the quality of the habitat matrix that the marten occupies (logged vs. unlogged forest); IBD was present in the continuous forest and absent in harvested forest fragments (Broquet et al. 2006). In this study we did not evaluate if spawning habitat characteristics were possible barriers to gene flow. However, previous research on sockeye salmon $(O$. nerka) observed high genetic differentiation between proximate populations that spawn in different habitats (i.e. lake, river, and stream habitats; Lin et al. 2008; McGlauflin et al. 2011). McGlauflin et al. (2011) found little evidence of IBD in sockeye salmon populations sampled from the same river drainage but they observed that genetic divergence among populations was correlated to differences in spawning habitat.

Water temperature is an important factor in embryo development (Murray and McPhail 1988) that can vary between spawning habitats. Genetically distinct summer and fall spawning chum salmon populations in the Yukon River drainage experience different thermal regimes at spawning sites (Zimmerman and Finn 2012), suggesting localized adaptation to spawning environment. Five out of nine populations identified as outliers by decomposed pairwise regression analysis (Ruby's Lagoon-24, Karluk Lagoon-47, Big Sukhoi-49, Sitkinak Island-51, and Gull Cape Lagoon-57) were sampled in spawning grounds near or adjacent to lagoons. It is possible that these lagoon habitats might be characterized by warmer water temperatures, and that spawning habitat selectivity restricts gene flow between adjacent populations. We did not collect environmental data to test this hypothesis but future research could use a landscape genomics approach to explore these interesting patterns of genetic differentiation (Allendorf et al. 2010) and uncover possible environmental factors influencing gene flow. If ecological data (water temperature, dissolved oxygen, sediment loads, etc.) on spawning grounds were obtained, then it would be possible to test for correlations between differences in environmental variables and genetic differentiation (Manel et al. 2003).

Regional differences in IBD slope when outlier populations are omitted

Multiple studies have observed variable IBD patterns across a single species range (Hutchison and Templeton 1999; Castric and Bernatchez 2003; Garnier et al. 2004). A metanalysis of IBD in fish species (Bradbury and Bentzen 2007) has shown that IBD relationships can vary depending on the spatial scale examined, due to localized differences in migration and time since populations have been present in a region. Theoretical models (Le Corre and Kremer 1998) indicate that areas recently colonized by a stepping stone model of migration exhibit less genetic differentiation than areas colonized for a longer period of time. These findings suggest that IBD is influenced by the genetic diversity of colonizing populations, time since colonization, and the spatial path of migration.

When IBD in non-outlier populations was explored on a regional basis (North Alaska Peninsula, South Alaska Peninsula, and Kodiak Island), different patterns emerged (Fig. 4). On the North Alaska Peninsula, populations were highly differentiated and there was a large variance in mean $F_{S T}$ values (Fig. 5). This finding can be explained in two different ways that invoke either contemporary or historical restrictions to gene flow. One possibility is that the magnitude of contemporary migration is not equal between all populations; instead, certain populations might be connected by high gene flow while others exchange very few migrants. A second hypothesis is that the relatively 
high genetic differentiation on the North Alaska Peninsula is caused by historically isolated founder populations. Seeb and Crane (1999) postulated that the North Alaska Peninsula is a secondary contact zone between lineages originating from the northern and southern parts of the species range. These allopatric founding populations colonized the Alaska Peninsula sometime after the Cordilleran Ice Sheet receded approximately 14,000 years ago. The secondary contact hypothesis is supported by multivariate analyses of allozyme genotypes (Seeb and Crane 1999) demonstrating that populations from the northeastern Alaska Peninsula are similar to populations from the northern range of the species (western Alaska and Russia) while populations from the northwestern Alaska Peninsula are similar to populations from the southern part of the range (British Columbia and Washington State). In addition, research (Petrou et al. in press) has suggested that secondary contact might have occurred recently due to the destruction of coastal spawning habitats by tectonic activity and abrupt changes in regional sea level (Jordan 2001).

Populations from the South Alaska Peninsula were characterized by much smaller pairwise $F_{S T}$ and an IBD slope that was an order of magnitude smaller than that found on the North Alaska Peninsula (Figs. 4, 5). Genetic differentiation and geographic distance separating populations were weakly correlated (Fig. 4 ), and $F_{S T}$ variance was relatively high at small spatial scales (Fig. 5). This pattern is consistent with a scenario of recent colonization of the South Alaska Peninsula by genetically homogeneous founder populations, in which insufficient time has passed for genetic drift to result in IBD among populations. Hutchison and Templeton (1999) found a similar pattern in populations of eastern collared lizards (Crotaphytus collaris collaris) in Kansas and concluded that the species had not occupied the region long enough for populations to approach IBD.

On Kodiak Island, there was a relatively strong correlation between genetic and geographic distance $\left(R^{2}=0.48\right)$. In addition, $F_{S T}$ variance was low at small geographic distances, and increased over larger spatial scales (Fig. 5). A study on anadromous brook char (Salvelinus fontinalis) observed similar fading of IBD relationship at larger geographic distances (Castric and Bernatchez 2003), presumably because long distance migration events are rare. Thus, we conclude that the genetic divergence of non-outlier populations on Kodiak Island is strongly influenced by the waterway distance separating populations.

\section{Comparison of nuclear and mitochondrial variation}

By incorporating loci from both nuclear and mitochondrial genomes we were able to gain unexpected insights into the genetic diversity of chum salmon. The majority of populations surveyed in the region were fixed for a single haplotype at two mtDNA SNPs (Oke_Cr30 and Oke_Cr386). However, in three westernmost populations (18-Little John Lagoon, 19-Sandy Cove, and 21-Delta Creek) we found a high proportion of individuals with a haplotype that is characteristic of Asian population (Sato et al. 2004). Interestingly, these Alaska populations showed little differentiation at nuclear DNA loci (Fig. 2b). Discordance between nuclear and mitochondrial genomes has been documented in a diversity of animal taxa (Humphries and Winker 2011; Hoffman et al. 2009; Toews and Brelsford 2012). There are multiple factors that can uncouple the evolutionary history of nuclear and mtDNA, including selection, genetic drift, sex-biased gene flow, and mtDNA introgression. At present, it is unclear which of these factors are responsible for the observed genetic patterns but these mtDNA loci will provide increased resolution for population structure or mixture analyses.

\section{Conclusion}

We have shown that chum salmon populations on the Alaska Peninsula and Kodiak Island contain considerable genetic diversity for the species. Genetic population structure appeared to be influenced by the geographic distance separating populations and the glacial history of Alaska. In addition, fine-scale geographic sampling revealed that the statistical significance and slope of IBD were very different depending on the geographic region examined (North Alaska Peninsula, South Alaska Peninsula, and Kodiak Island); this is likely caused by the presence of refugial populations on Kodiak Island and secondary contact on the North Alaska Peninsula. The finescale genetic dataset that we have assembled will help inform conservation strategies as fisheries managers continue to evaluate the impacts of bycatch and monitor the long-term productivity of chum salmon populations.

Acknowledgments This project was a collaborative effort between the University of Washington, School of Aquatic and Fishery Sciences (UW SAFS) and the Alaska Department of Fish and Game (ADFG). Colleagues from the ADFG (Nick Decovich, Lisa Fox, Penny Crane, and Judy Berger) conducted field sampling, organized data sharing, and assisted with DNA extractions. Carita Pascal and Heather Peterson (UW SAFS) gave indispensable laboratory support. We thank Robin Waples (National Oceanic and Atmospheric Administration-NOAA), Penny Crane (U. S. Fish and Wildlife Service), and Pat Martin for many productive discussions and observations about the potential effects of glacial history on salmon. Morten Limborg, Fred Utter, Einar E. Nielsen, and two anonymous reviewers contributed insightful comments on drafts of the manuscript. This research was partially funded by the Alaska Sustainable Salmon Fund under Study \# 45919 from NOAA, US Department of Commerce, administered by the ADFG. The statements, findings, conclusions, and recommendations are those of the authors and do not necessarily 
reflect the views of the NOAA, the U.S. Department of Commerce, or the ADFG. Additional funding was provided by the Gordon and Betty Moore Foundation and the State of Alaska. A National Science Foundation GK-12 graduate teaching fellowship through the Ocean and Coastal Interdisciplinary Science Program (OACIS, proposal number DGE-0742559) provided ELP with additional funding during the final year of study.

Open Access This article is distributed under the terms of the Creative Commons Attribution License which permits any use, distribution, and reproduction in any medium, provided the original author(s) and the source are credited.

\section{References}

Allendorf FW, England PR, Luikart G, Ritchie PA, Ryman N (2008) Genetic effects of harvest on wild animal populations. Trends Ecol Evol 23(6):327-337. doi:10.1016/j.tree.2008.02.008

Allendorf FW, Hohenlohe PA, Luikart G (2010) Genomics and the future of conservation genetics. Nat Rev Genet 11(10):697-709. doi: $10.1038 / \operatorname{nrg} 2844$

Barnes VG Jr. (1990) The influence of salmon availability on movements and range of brown bears on southwest Kodiak Island. Bears: Biol Manag 8:305-313. doi:10.2307/3872933

Bradbury IR, Bentzen P (2007) Non-linear genetic isolation by distance: implications for dispersal estimation in anadromous and marine fish populations. Mar Ecol Prog Ser 340:245-257. doi: $10.3354 / \mathrm{meps} 340245$

Broquet T, Ray N, Petit E, Fryxell J, Burel F (2006) Genetic isolation by distance and landscape connectivity in the American marten (Martes americana). Landscape Ecol 21(6):877-889. doi:10. 1007/s10980-005-5956-y

Burnham KP, Anderson DR (2002) Model selection and multimodel inference: a practical information-theoretic approach, 2nd edn. Springer, New York

Castric V, Bernatchez L (2003) The rise and fall of isolation by distance in the anadromous brook charr (Salvelinus fontinalis Mitchill). Genetics 163(3):983-996

Clark PU, Dyke AS, Shakun JD, Carlson AE, Clark J, Wohlfarth B, Mitrovica JX, Hostetler SW, McCabe AM (2009) The last glacial maximum. Science 325(5941):710-714. doi:10.1126/ science. 1172873

Coulon A, Cosson JF, Angibault JM, Cargnelutti B, Galan M, Morellet N, Petit E, Aulagnier S, Hewison AJM (2004) Landscape connectivity influences gene flow in a roe deer population inhabiting a fragmented landscape: an individualbased approach. Mol Ecol 13(9):2841-2850. doi:10.1111/j.1365294X.2004.02253.x

Cunningham KM, Canino MF, Spies IB, Hauser L (2009) Genetic isolation by distance and localized fjord population structure in Pacific cod (Gadus macrocephalus): limited effective dispersal in the northeastern Pacific Ocean. Can J Fish Aquat Sci 66(1): $153-166$

Elfstrom CM, Smith CT, Seeb LW (2007) Thirty-eight single nucleotide polymorphism markers for high-throughput genotyping of chum salmon. Mol Ecol Notes 7(6):1211-1215. doi:10. 1111/j.1471-8286.2007.01835.x

Excoffier L, Lischer HEL (2010) Arlequin suite ver 3.5: a new series of programs to perform population genetics analyses under Linux and Windows. Mol Ecol Res 10(3):564-567. doi:10.1111/ j.1755-0998.2010.02847.x
Faustini MA (1999) Abundance and run timing of adult chum salmon in the Sturgeon River, Kodiak, Alaska, 1998. US Fish and Wildlife Service. http://alaska.fws.gov/fisheries/fish/Data_ Series/d_1999_2.pdf. Accessed 02 Dec 2012

Garnier S, Alibert P, Audiot P, Prieur B, Rasplus JY (2004) Isolation by distance and sharp discontinuities in gene frequencies: implications for the phylogeography of an alpine insect species, Carabus solieri. Mol Ecol 13(7):1883-1897. doi:10.1111/j.1365294X.2004.02212.x

Gisclair BR (2009) Salmon bycatch management in the Bering Sea walleye pollock fishery: threats and opportunities for Western Alaska. In: Krueger CC, Zimmerman CE (eds) Pacific Salmon: ecology and management of Western Alaska's populations. American Fisheries Society, Bethesda, pp 799-816

Haflinger K, Gruver J (2009) Rolling hot spot closure areas in the Bering Sea walleye pollock fishery: estimated reduction of salmon bycatch during the 2006 season. In: Krueger CC, Zimmerman CE (eds) Pacific Salmon: ecology and management of Western Alaska's populations. American Fisheries Society, Bethesda, pp 817-826

Hellberg ME (1994) Relationships between inferred levels of gene flow and geographic distance in a philopatric coral, Balanophyllia elegans. Evolution 48(6):1829-1854

Hendry AP, Day T (2005) Population structure attributable to reproductive time: isolation by time and adaptation by time. Mol Ecol 14(4):901-916. doi:10.1111/j.1365-294X.2005.02480.x

Hilborn R, Quinn TP, Schindler DE, Rogers DE (2003) Biocomplexity and fisheries sustainability. Proc Natl Acad Sci 100(11): 6564-6568. doi:10.1073/pnas.1037274100

Hoffman JI, Dasmahapatra KK, Amos W, Phillips CD, Gelatt TS, Bickham JW (2009) Contrasting patterns of genetic diversity at three different genetic markers in a marine mammal metapopulation. Mol Ecol 18(14):2961-2978. doi:10.1111/j.1365-294X. 2009.04246.x

Humphries EM, Winker K (2011) Discord reigns among nuclear, mitochondrial and phenotypic estimates of divergence in nine lineages of trans-Beringian birds. Mol Ecol 20(3):573-583. doi:10.1111/j.1365-294X.2010.04965.x

Hutchison DW, Templeton AR (1999) Correlation of pairwise genetic and geographic distance measures: inferring the relative influences of gene flow and drift on the distribution of genetic variability. Evolution 53(6):1898-1914

Jombart T (2008) Adegenet: a R package for the multivariate analysis of genetic markers. Bioinformatics 24(11):1403-1405. doi:10. 1093/bioinformatics/btn129

Jordan J (2001) Late Quaternary sea level change in Southern Beringia: postglacial emergence of the Western Alaska Peninsula. Quatern Sci Rev 20(1-3):509-523

Karlstrom TNV, Ball G (1969) The Kodiak Island Refugium. Ryerson Press, Boreal Institute, University of Alberta, Calgary

Kimura M, Weiss GH (1964) The stepping stone model of population structure and the decrease of genetic correlation with distance. Genetics 49(4):561-576

Koizumi I, Yamamoto S, Maekawa K (2006) Decomposed pairwise regression analysis of genetic and geographic distances reveals a metapopulation structure of stream-dwelling Dolly Varden charr. Mol Ecol 15(11):3175-3189. doi:10.1111/j.1365-294X.2006. 03019.x

Le Corre V, Kremer A (1998) Cumulative effects of founding events during colonisation on genetic diversity and differentiation in an island and stepping-stone model. J Evol Biol 11(4):495-512. doi:10.1046/j.1420-9101.1998.11040495.x

Lin J, Quinn TP, Hilborn R, Hauser L (2008) Fine-scale differentiation between sockeye salmon ecotypes and the effect of phenotype on straying. Heredity 101(4):341-350. doi:10.1038/hdy.2008.59 
Manel S, Schwartz MK, Luikart G, Taberlet P (2003) Landscape genetics: combining landscape ecology and population genetics. Trends Ecol Evol 18(4):189-197. doi:10.1016/S0169-5347(03)00008-9

Mann DH, Hamilton TD (1995) Late Pleistocene and Holocene paleoenvironments of the North Pacific coast. Quatern Sci Rev 14(5):449-471. doi:10.1016/0277-3791(95)00016-I

Mann DH, Peteet DM (1994) Extent and timing of the last glacial maximum in southwestern Alaska. Quatern Res 42(2):136-148. doi:10.1006/qres 1994.1063

McGlauflin MT, Schindler DE, Seeb LW, Smith CT, Habicht C, Seeb JE (2011) Spawning habitat and geography influence population structure and juvenile migration timing of sockeye salmon in the Wood River lakes, Alaska. Trans Am Fish Soc 140(3):763-782. doi: 10.1080/00028487.2011.584495

Murray CB, McPhail JD (1988) Effect of incubation temperature on the development of five species of Pacific salmon (Oncorhynchus) embryos and alevins. Can J Zool 66(1):266-273. doi:10. 1139/z88-038

Musslewhite J (2011) An evaluation of the Kitoi Bay Salmon Hatchery for consistency with statewide policies and prescribed management policies. http://www.adfg.alaska.gov/static/fishing/ PDFs/hatcheries/RIR.5J.2011.01.pdf. Accessed 20 Dec 2012

Olsen JB, Flannery BG, Beacham TD, Bromaghin JF, Crane PA, Lean CF, Dunmall KM, Wenburg JK (2008) The influence of hydrographic structure and seasonal run timing on genetic diversity and isolation-by-distance in chum salmon (Oncorhynchus keta). Can J Fish Aquat Sci 65(9):2026-2042

Oyler-McCance S, Fedy B, Landguth E (2012) Sample design effects in landscape genetics. Conserv Genet 1-11. doi:10.1007/s10592012-0415-1

Palsbøll PJ, Bérubé M, Allendorf FW (2007) Identification of management units using population genetic data. Trends Ecol Evol 22(1):11-16. doi:10.1016/j.tree.2006.09.003

Peakall R, Smouse P (2006) Genalex 6: genetic analysis in Excel. Population genetic software for teaching and research. Mol Ecol Notes 6:288-295. doi:10.1111/j.1471-8286.2005.01155.x

Pearse D, Martinez E, Garza J (2011) Disruption of historical patterns of isolation by distance in coastal steelhead. Conserv Genet 12(3):691-700. doi:10.1007/s10592-010-0175-8

Petrou EL, Hauser L, Waples RS, Seeb JE, Templin WD, GomezUchida D, Seeb LW (in press) Secondary contact and changes in coastal habitat availability influence the non-equilibrium population structure of a salmonid (Oncorhynchus keta). Mol Ecol

Phelps SR, LeClair LL, Young S, Blankenship HL (1994) Genetic diversity patterns of Chum Salmon in the Pacific Northwest. Can J Fish Aquat Sci 51(S1):65-83. doi:10.1139/f94-296

R Core Team (2013). R: A language and environment for statistical computing. R Foundation for Statistical Computing, Vienna, Austria. http://www.R-project.org/.

Raymond M, Rousset F (1995) Genepop version 1.2: population genetics software for exact tests and ecumenicism. J Hered $86: 248-249$

Rousset F (1997) Genetic differentiation and estimation of gene flow from F-statistics under isolation by distance. Genetics 145(4): $1219-1228$

Rousset F (2008) Genepop'007: a complete reimplementation of the Genepop software for Windows and Linux. Mol Ecol Res 8:103-106. doi:10.1111/j.1471-8286.2007.01931.x

Ryman N (2006) Chifish: a computer program testing for genetic heterogeneity at multiple loci using Chi square and Fisher's exact test. Mol Ecol Notes 6(1):285-287. doi:10.1111/j.14718286.2005.01146.x

Sato S, Kojima H, Ando J, Ando H, Wilmot R, Seeb L, Efremov V, LeClair L, Buchholz W, Jin D-H, Urawa S, Kaeriyama M, Urano A, Abe S (2004) Genetic population structure of chum salmon in the Pacific rim inferred from mitochondrial DNA sequence variation. Environ Biol Fishes 69(1):37-50. doi:10.1023/B: EBFI.0000022881.90237.aa

Schindler DE, Hilborn R, Chasco B, Boatright CP, Quinn TP, Rogers LA, Webster MS (2010) Population diversity and the portfolio effect in an exploited species. Nature 465(7298):609-612. doi:10.1038/nature09060

Schwartz M, McKelvey K (2009) Why sampling scheme matters: the effect of sampling scheme on landscape genetic results. Conserv Genet 10(2):441-452. doi:10.1007/s10592-008-9622-1

Seeb LW, Crane PA (1999) High genetic heterogeneity in chum salmon in Western Alaska, the contact zone between northern and southern lineages. Trans Am Fish Soc 128(1):58-87. doi:10. 1577/1548-8659(1999)128<0058:HGHICS $>2.0 . C O ; 2$

Seeb JE, Pascal CE, Ramakrishnan R, Seeb LW (2009) SNP genotyping by the $5^{\prime}$-nuclease reaction: advances in high throughput genotyping with non-model organisms. In: Komar A (ed) Methods in molecular biology, single nucleotide polymorphisms, 2nd edn. Humana Press, New York, pp 277-292

Seeb JE, Pascal CE, Grau ED, Seeb LW, Templin WD, Harkins T, Roberts SB (2011a) Transcriptome sequencing and high-resolution melt analysis advance single nucleotide polymorphism discovery in duplicated salmonids. Mol Ecol Resour 11(2):335-348. doi:10.1111/j.1755-0998.2010.02936.x

Seeb LW, Templin WD, Sato S, Abe S, Warheit K, Park JY, Seeb JE (2011b) Single nucleotide polymorphisms across a species' range: implications for conservation studies of Pacific salmon. Mol Ecol Res 11:195-217. doi:10.1111/j.1755-0998.2010. 02966.x

Slatkin M (1993) Isolation by distance in equilibrium and nonequilibrium populations. Evolution 47(1):264-279

Smith CT, Baker J, Park L, Seeb LW, Elfstrom C, Abe S, Seeb JE (2005a) Characterization of 13 single nucleotide polymorphism markers for chum salmon. Mol Ecol Notes 5(2):259-262. doi:10. 1111/j.1471-8286.2005.00903.x

Smith CT, Elfstrom CM, Seeb LW, Seeb JE (2005b) Use of sequence data from rainbow trout and Atlantic salmon for SNP detection in Pacific salmon. Mol Ecol 14(13):4193-4203. doi:10.1111/j. 1365-294X.2005.02731.x

Tallman RF, Healey MC (1994) Homing, straying, and gene flow among seasonally separated populations of chum salmon (Oncorhynchus keta). Can J Fish Aquat Sci 51(3):577-588. doi:10. 1139/f94-060

Taylor BL, Dizon AE (1999) First policy then science: why a management unit based solely on genetic criteria cannot work. Mol Ecol 8:S11-S16. doi:10.1046/j.1365-294X.1999.00797.x

Taylor EB, Stamford MD, Baxter JS (2003) Population subdivision in westslope cutthroat trout (Oncorhynchus clarki lewisi) at the northern periphery of its range: evolutionary inferences and conservation implications. Mol Ecol 12(10):2609-2622. doi:10. 1046/j.1365-294X.2003.01937.x

Toews DPL, Brelsford A (2012) The biogeography of mitochondrial and nuclear discordance in animals. Mol Ecol 21(16): 3907-3930. doi:10.1111/j.1365-294X.2012.05664.x

Utter F, Ryman N (1993) Genetic markers and mixed stock fisheries. Fisheries 18(8):11-21. doi:10.1577/1548-8446(1993)018<0011: gmamsf $>2.0 . \mathrm{co} ; 2$

Waples RS (1990) Temporal changes of allele frequency in Pacific salmon: implications for mixed-stock fishery analysis. Can J Fish Aquat Sci 47(5):968-976. doi:10.1139/f90-111

Waples RS, Do C (2008) LDNE: a program for estimating effective population size from data on linkage disequilibrium. Mol Ecol Res 8(4):753-756. doi:10.1111/j.1755-0998.2007.02061.x

Waples RS, Teel DJ, Myers JM, Marshall AR (2004) Life-history divergence in Chinook salmon: historic contingency and parallel evolution. Evolution 58(2):386-403. doi:10.1111/j.0014-3820. 2004.tb01654.x 
Weir B, Cockerham C (1984) Estimating F-statistics for the analysis of population structure. Evolution 38(6):1358-1370

Wolfe RJ (2004) Local traditions and subsistence: a synopsis from 25 years of research by the state of Alaska. Alaska Department of Fish and Game. http://www.adfg.alaska.gov/techpap/Tp284. pdf. Accessed 12 Aug 2012
Wright S (1931) Evolution in Mendelian populations. Genetics 16(2):97-159

Wright S (1943) Isolation by distance. Genetics 28(2):114-138

Zimmerman CE, Finn JE (2012) A simple method for in situ monitoring of water temperature in substrates used by spawning salmonids. J Fish Wildl Manag 3(2):1-8 